\title{
Involvement of outer-membrane proteins in the aggregation of Azospirillum brasilense
}

\author{
Saul Burdman, ${ }^{1}$ Edouard Jurkevitch, ${ }^{1}$ Boris Schwartsburd ${ }^{2}$ \\ and Yaacov Okon'
}

Author for correspondence: Yaacov Okon. Tel: +972 89481216 . Fax: +972 89466794. e-mail: okon@agri.huji.ac.il

\begin{abstract}
Department of Plant Pathology and Microbiology, and The Otto Warburg Center for Agricultural Biotechnology 1 , and Department of Animal Sciences ${ }^{2}$, Faculty of Agricultural, Food and Environmental Quality Sciences, The Hebrew University of Jerusalem, Rehovot 76100, Israel
\end{abstract}

\begin{abstract}
A bioassay was developed to investigate biological factors involved in the aggregation of Azospirillum brasilense strain Cd. Cells were grown for $\mathbf{2 4} \mathrm{h}$ under aggregation-inducing and non-aggregation-inducing conditions (high and low C:N, respectively) and sonicated for $20 \mathrm{~s}$. The cells were washed by centrifugation and resuspended in potassium phosphate buffer containing the two types of sonication extract. A greater extent of aggregation and higher flocculation were observed after 2-3 h incubation in the presence of sonicates from cells grown at high $\mathrm{C}: \mathrm{N}$ (H-cells) compared to cells grown at low $\mathrm{C}: \mathrm{N}$. Flocculation did not occur after incubation of these cells in phosphate buffer. Boiled or proteinase K-treated sonicates originating from H-cells had lower aggregation-inducing capacity. After fractionation of the crude sonicate, both the outer-membrane protein (OMP) and the total membrane (mostly OMP) fractions possessed relatively high aggregation specific activities. The aggregation-inducing capacity of the OMP fraction strongly correlated with its protein concentration in the bioassay. Treatment of this fraction with proteinase $K$ also decreased its aggregation-inducing activity. These findings suggest that OMPs are involved in the aggregation process of cells of $A$. brasilense.
\end{abstract}

Keywords: Azospirillum brasilense, aggregation, flocculation, outer-membrane proteins

\section{INTRODUCTION}

The free-living $\mathrm{N}_{2}$-fixing rhizobacterium Azospirillum brasilense lives in close association with plant roots and may exert beneficial effects on plant growth and yield of many crops of agronomic importance (Okon \& Labandera-Gonzalez, 1994). This and other plantgrowth-promoting rhizobacteria (PGPR) are known for their capacity to aggregate and flocculate, and this property may positively affect their dispersal and survival in soil (Nur et al., 1981; Sadasivan \& Neyra, 1985; Madi et al., 1988; Madi \& Henis, 1989). Thus, the phenomenon of bacterial aggregation has considerable importance in the production of inoculants for agriculture.

The bacterial surface plays an important role in the establishment of bacteria-plant associations as well as in bacterial aggregation (De Troch \& Vanderleyden, 1996). Data suggesting the involvement of extracellular

Abbreviations: EPS, exopolysaccharide; H-cells, high $\mathrm{C}: \mathrm{N}$-grown cells; Lcells, low C:N-grown cells; (M)OMP, (major) outer-membrane protein. polysaccharides and proteins in aggregation of Azospirillum have been published (Sadasivan \& Neyra, 1985; Madi \& Henis, 1989; Michiels et al., 1990, 1991; Katupitiya et al., 1995; Burdman et al., 1998). However, the mechanism of aggregation and the molecules involved in cell-to-cell adhesion are still unknown. Recently, a regulatory gene of $A$. brasilense was identified and proposed to be involved in the regulation of aggregation, capsule production and colonization of root surface (Pereg-Gerk et al., 1998). Nikitina et al. (1996) and Castellanos et al. (1998) suggested the presence of cell-surface lectins in Azospirillum that could be involved in cell aggregation and bacterial adhesion to roots.

Direct evidence for the involvement of extracellular proteins in the adhesion process of Azospirillum to abiotic surfaces has been provided (Dufrêne et al., 1996a, b; Dufrêne \& Rouxhet, 1996). Extracellular proteins have been suggested to participate directly in the aggregation of various bacterial species from diverse environments (Eggset et al., 1983; Calleja, 1984; Marsh \& Bradshaw, 1995; Wai et al., 1996). 
Azospirillum cells aggregate and flocculate under diverse stress conditions and in the presence of various carbon sources, this phenomenon being generally accompanied by an accumulation of polyhydroxybutyrate (PHB) granules (Sadasivan \& Neyra, 1985; Burdman et al., 1998). In previous work (Burdman et al., 1998) we developed a medium for consistent induction of aggregation of A. brasilense cells and studied the effects of chemical and physical factors on this phenomenon. Growth of $A$. brasilense strain $\mathrm{Cd}$ in a medium with a high $\mathrm{C}: \mathrm{N}$ ratio (using fructose and ammonium chloride as $\mathrm{C}$ and $\mathrm{N}$ sources, respectively) resulted in flocculation visible to the naked eye after $24 \mathrm{~h}$, whereas no cell aggregates were formed after $72 \mathrm{~h}$ of growth in low $\mathrm{C}: \mathrm{N}$ medium. The same study describes an effective method for temporarily disrupting flocs by sonication of the cells for a relatively short period $(20 \mathrm{~s})$. This treatment was shown to be very effective in releasing proteins (most probably those attached to the cell surface) without a drastic reduction in cell viability (Burdman et al., 1998). Based on these findings, a suitable bioassay was developed to investigate the nature of biological factors involved in cell-to-cell adhesion leading to aggregation. This bioassay procedure is described in this paper together with the first results using this system.

\section{METHODS}

A. brasilense strains and growth conditions. Wild-type strains Cd (Eskew et al., 1977) and Sp7 (Tarrand et al., 1978), and strains FAJ0204, a Tn5 mutant of Sp7 defective in the production of both lateral and polar flagella (kindly supplied by J. Vanderleyden, Catholic University of Leuven, Belgium), and Sp72002 (Pereg-Gerk et al., 1998), a pleiotrophic Tn5 mutant of $\mathrm{Sp} 7$ affected in its aggregation capacity (kindly supplied by C. Elmerich, Institut Pasteur, Paris, France), were maintained on nutrient agar (Difco) slants. Kanamycin was added at $50 \mathrm{~g} \mathrm{ml}^{-1}$ for the Tn5 mutant strains. Bacteria were grown under aggregation- or non-aggregation-inducing conditions (high and low $C: N$, respectively). The high $C: N$ medium contained $\left(\mathrm{g} \mathrm{I}^{-1}\right)$ D-fructose $(6 \cdot 67), \mathrm{MgSO}_{4}(0 \cdot 2), \mathrm{NaCl}$ $(0 \cdot 1), \mathrm{CaCl}_{2}(0 \cdot 02), \mathrm{K}_{2} \mathrm{HPO}_{4}(6 \cdot 0), \mathrm{KH}_{2} \mathrm{PO}_{4}(4 \cdot 0)$, yeast extract (Difco) $(0 \cdot 1), \mathrm{NH}_{4} \mathrm{Cl}(0 \cdot 214)$ and microelements as described by Okon et al. (1977). The low $\mathrm{C}: \mathrm{N}$ medium contained the same components, but with $\mathrm{NH}_{4} \mathrm{Cl}$ at $0.963 \mathrm{~g} \mathrm{l}^{-1}$. Liquid media were adjusted to $\mathrm{pH} 6 \cdot 8$. Flasks with $100 \mathrm{ml}$ medium were inoculated with exponential-phase cultures at an initial $\mathrm{OD}_{540}$ of approximately 0.05 (about $10^{7}$ c.f.u. $\mathrm{ml}^{-1}$ ) and incubated on a rotary shaker ( 150 r.p.m.) at $30^{\circ} \mathrm{C}$ for $24 \mathrm{~h}$ (until late exponential phase in both media).

Quantitative measurement of aggregation. The extent of aggregation was measured according to Madi \& Henis (1989) with some modifications. Aliquots of suspensions containing aggregates were transferred to a conical tube and allowed to stand. After $20 \mathrm{~min}$ at $24^{\circ} \mathrm{C}$, aggregates had settled to the bottom of the tube and the suspension was mostly composed of free cells. The turbidity of the suspension was measured using a Genesis 5 spectrophotometer (Spectronic) at $540 \mathrm{~nm}$ $\left(\mathrm{OD}_{\mathrm{s}}\right)$. The culture was then dispersed by treatment in a tissue homogenizer (Heidolph RzR 50) for $1 \mathrm{~min}$ and the total turbidity was measured immediately $\left(\mathrm{OD}_{\mathrm{t}}\right)$. The percentage aggregation was estimated as follows: percentage aggregation $=\left(O D_{t}-O D_{s}\right) \times 100 / O_{t}$. While aggregation is reflected in the value measured as described above, flocculation, on the other hand, is defined as the formation of visible aggregates (flocs) and was expressed in this study as a qualitative parameter.

The aggregation bioassay. Cells were grown in high or low $\mathrm{C}: \mathrm{N}$ medium (H- and L-cells, respectively; $300 \mathrm{ml}$ for $\mathrm{H}$-cells and $200 \mathrm{ml}$ for L-cells) as described above. Approximately $0.3 \mathrm{~g}$ total bacterial dry weight was used in each experiment. Cells were centrifuged $(4000 \mathrm{~g}, 10 \mathrm{~min}$, twice), resuspended in $10 \mathrm{mM}$ potassium phosphate buffer $(\mathrm{pH} 6 \cdot 8)$ and finally sonicated in an ultrasonic disintegrator (MSE) at $1.2 \mathrm{~A}$ for $20 \mathrm{~s}$ on ice. The centrifuged supernatant of sonicated cells $(5000 \mathrm{~g}$, $15 \mathrm{~min})$ was filtered $(0.45 \mu \mathrm{m})$ and designated the sonicate extract (or sonicate). The final extraction volume was made up to $60 \mathrm{ml}$ with phosphate buffer. Pelleted sonicated cells were resuspended in $10 \mathrm{ml}$ phosphate buffer. Bioassays were carried out in $50 \mathrm{ml}$ conical tubes (Miniplast Ein-Shemer) as follows : $10 \mathrm{ml}$ sonicate or its fractions (see below) were added to $0.5 \mathrm{ml}$ bacterial suspension in phosphate buffer and made up to a total volume of $15 \mathrm{ml}$. Negative controls were supplemented with phosphate buffer alone. Tubes were incubated at $30^{\circ} \mathrm{C}$ with shaking (150 r.p.m.). Minor variations are described in Results and Discussion.

Effects of boiling and treatment with proteases on the aggregation-inducing activity of the sonicate extract. Sonicates from $\mathrm{H}$-cells were treated with proteinase $\mathrm{K}$ (EC 3.4.21.64, from Tritirachium album; Sigma) or trypsin (EC 3.4.21.4, from beef pancreas; BDH) at $1.0 \mathrm{mg} \mathrm{ml}^{-1}$ for $3 \mathrm{~h}$ at $37^{\circ} \mathrm{C}$, or alternatively boiled for $20 \mathrm{~min}$ before the onset of the bioassay in which sonicated L-cells were used. Controls included phosphate buffer alone, sonicate incubated at $37{ }^{\circ} \mathrm{C}$ for $3 \mathrm{~h}$ without proteases or with boiled enzymes, and sonicate alone kept at $4{ }^{\circ} \mathrm{C}$ until the bioassay (fresh sonicate).

Fractionation of the sonicates. Cells were grown in high $\mathrm{C}: \mathrm{N}$ medium for $24 \mathrm{~h}$, centrifuged $(4000 \mathrm{~g}, 10 \mathrm{~min}$, twice), resuspended in $10 \mathrm{mM}$ phosphate buffer and then sonicated for $5 \mathrm{~min}$. After centrifugation $(5000 \mathrm{~g}, 15 \mathrm{~min})$ and filtration $(0.45 \mu \mathrm{m})$ the supernatant was divided into two equal volumes: the 'crude sonicate' and a second fraction that was further purified by ultra-centrifugation $(100000 \mathrm{~g}, 1 \mathrm{~h})$. The supernatant of this centrifugation stage contained the "free protein fraction' (extracellular proteins weakly attached to the cell wall and cytoplasmic proteins, both released by sonication). The pellet was resuspended in $20 \mathrm{mM}$ Tris/HCl $(\mathrm{pH} \mathrm{7.2)} \mathrm{and}$ divided into two equal volumes. One volume contained the 'total membrane protein fraction'. The outer-membrane protein (OMP) fraction was obtained from the second volume according to Schloter et al. (1994). The bioassay was carried out on sonicated L-cells by applying the different fractions obtained from the same amount of bacterial dry weight as previously described.

Protein determination. The bioassay was initially developed on the basis of material extracted from a known dry weight of cells. In bioassays conducted after treatments such as boiling, proteases and fractionation, the protein concentration in the bioassay was determined according to Bradford (1976).

Gel electrophoresis. Proteins were separated by SDS-PAGE $(12 \%, \mathrm{w} / \mathrm{v}$, acrylamide $)$ and stained with Coomassie brilliant blue, using standard methods (Laemmli, 1970). The molecular masses of the proteins were estimated using low-range prestained standards (Bio-Rad). Relative quantification of proteins in SDS-PAGE gels was performed using NIH Image (1.61) software.

Statistics. Each experiment was carried out three times with three replicates per treatment in each one. Since results were 
highly reproducible, data from representative experiments are shown. Data were subjected to one- or two-way analysis of variance (ANOVA) for determination of significant differences between treatments.

\section{RESULTS AND DISCUSSION}

\section{Characterization of the bioassay system}

Sonicates obtained from various strains of A. brasilense differing in their aggregation capacity were tested for their effects on aggregation of $\mathrm{H}$-cells of strain $\mathrm{Cd}$ (aggregating $\mathrm{H}$-cells). The other strains were also grown under high C: N. FA J0204 and Sp72002 are Tn5-induced strains of Sp7. The first has a strong aggregative phenotype whereas the latter does not aggregate at all under the tested growth conditions. In previous work, wild-type strain $\mathrm{Sp} 7$ was shown to aggregate less than mutant FA J0204, but more than wild-type Cd (Burdman et al., 1998).

There is a clear effect of adding sonicates in inducing aggregation of $\mathrm{H}$-cells (Table 1 ). The aggregation rates of the various strains as measured by Burdman et al. (1998) and the aggregation-inducing activity of their extracts were positively correlated $\left(r^{2}=0.956\right)$. Sonicates from the highest aggregating strains (FAJ0204 and $\mathrm{Sp} 7$ ) significantly differed from controls and a

Table 1. Aggregation of $\mathrm{H}$-cells of $A$. brasilense strain $\mathrm{Cd}$ after $1 \mathrm{~h}$ incubation in $20 \mathrm{~s}$ sonicates of different strains of $A$. brasilense grown for $24 \mathrm{~h}$ under high $\mathrm{C}: \mathrm{N}$

\begin{tabular}{|lll|}
\hline Sonicate origin & Aggregation $(\%)^{*}$ & Flocculation \\
\hline Control $\dagger$ & $11 \cdot 0^{\mathrm{c}}$ & Intermediate \\
Sp72002 & $11 \cdot 6^{\mathrm{bc}}$ & Intermediate \\
Cd & $13 \cdot 2^{\mathrm{abc}}$ & Strong \\
Sp7 & $14 \cdot 3^{\mathrm{ab}}$ & Strong \\
FA J0204 & $15 \cdot 1^{\mathrm{a}}$ & Strong \\
\hline
\end{tabular}

*Different letters $(a-c)$ indicate significant differences between treatments at $P=0 \cdot 05$.

$\dagger$ In the control treatment, $\mathrm{H}$-cells were resuspended in phosphate buffer. clearly more intensive flocculation was observed when $\mathrm{H}$-cells were resuspended in sonicates originating from the three aggregating strains in comparison to controls and sonicates from strain Sp72002. Although some differences in percentage aggregation were not found to be statistically significant, the same picture was observed in two other separate experiments.

The aggregative capacity of the sonicates was further investigated using $\mathrm{H}$ - and L-cells. Strain Cd cells were grown under both conditions, sonicated for $20 \mathrm{~s}$ and resuspended in phosphate buffer alone and in buffer containing sonicates of $\mathrm{H}$ - or L-cells. In both cases, resuspension in sonicates from aggregating cells $(\mathrm{H}$ cells) showed significantly higher extents of aggregation in comparison to those obtained from non-aggregating cultures (L-cells) and controls (Table 2). It was also observed that sonicates from L-cells were more aggregation-inducing than controls with phosphate buffer alone. As expected, aggregation of $\mathrm{H}$-cells was higher and flocs appeared faster when compared to Lcells. H-cells flocculated within a few minutes after resuspension, whereas visible flocs of L-cells appeared only after $2-3 \mathrm{~h}$. Flocculation (appearance of visible aggregates) occurred in all treatments, except for L-cells resuspended in phosphate buffer, for which low extents of aggregation were still obtained. This result is explained by the formation of small clumps of cells (microaggregates) with a polar configuration that are visible only under the microscope, in both high and low C: $N$ cultures of strain Cd (Burdman et al., 1998).

The same procedure was applied to the non-aggregating mutant strain Sp72002. No flocculation occurred even after $24 \mathrm{~h}$ incubation of this strain in sonicates obtained from $\mathrm{H}$-cells of strain $\mathrm{Cd}$ (not shown). This mutant strain produces the least exopolysaccharide (EPS) of the four tested strains (Burdman et al., 1998), lacks thickening of the extracellular coat, does not form a polysaccharide net between cells (as observed for wildtype Sp7 during flocculation) and does not bind Congo Red like wild-type strains (Pereg-Gerk et al., 1998). Aggregation in our bioassay system may involve interaction between factor(s) from the sonicate and polysaccharides in the cell wall; the absence of some of the latter could explain the observed lack of aggregation.

Table 2. Aggregation of $\mathrm{H}$ - and L-cells of $A$. brasilense strain $\mathrm{Cd}$ after incubation in their own or reciprocal sonicates

Controls were resuspended in phosphate buffer. $\mathrm{H}$-cells were incubated for $1 \mathrm{~h}$, whereas $\mathrm{L}$-cells were incubated for $2 \mathrm{~h}$. Different letters $(\mathrm{a}-\mathrm{c})$ indicate significant differences between treatments at $P=$ $0 \cdot 05$ (sonicate origins) in each type of cell.

\begin{tabular}{|c|c|c|c|c|}
\hline \multirow[t]{2}{*}{ Sonicate origin } & \multicolumn{2}{|c|}{ L-cells } & \multicolumn{2}{|c|}{ H-cells } \\
\hline & Aggregation (\%) & Flocculation & Aggregation (\%) & Flocculation \\
\hline Control & $3 \cdot 1^{c}$ & None & $8 \cdot 4^{\mathrm{b}}$ & Intermediate \\
\hline L-cells & $7 \cdot 3^{b}$ & Weak & $9 \cdot 9^{\mathrm{h}}$ & Intermediate \\
\hline H-cells & $8 \cdot 7^{\mathrm{a}}$ & Intermediate & $13 \cdot 9^{\mathrm{a}}$ & Strong \\
\hline
\end{tabular}


Table 3. Effects of pre-sonication on L-cells of $A$. brasilense strain $\mathrm{Cd}$ used in the bioassay

The extent of aggregation after $4 \mathrm{~h}$ incubation of sonicated and non-sonicated cells in phosphate buffer (control) and $20 \mathrm{~s}$ sonicate of $\mathrm{L}$ - and $\mathrm{H}$-cells is shown. Different letters $(\mathrm{a}-\mathrm{b})$ indicate significant differences between the different type of cells at $P=0.05$ (sonicated or not) in each incubation treatment.

\begin{tabular}{|lcccc|}
\hline Sonicate origin & \multicolumn{2}{c|}{ Sonicated L-cells } & & \multicolumn{2}{c|}{ Non-sonicated L-cells } \\
\cline { 2 - 3 } \cline { 5 - 5 } & Aggregation $(\%)$ & Flocculation & Aggregation (\%) & Flocculation \\
\hline Control & $13 \cdot 0^{\mathrm{a}}$ & - & $2 \cdot 9^{\mathrm{b}}$ & - \\
L-cells & $22 \cdot 8^{\mathrm{a}}$ & + & $9 \cdot 4^{\mathrm{b}}$ & - \\
H-cells & $26 \cdot 4^{\mathrm{a}}$ & + & $11 \cdot 2^{\mathrm{b}}$ & - \\
\hline
\end{tabular}

Table 4. Effects of different treatments on the aggregation-inducing activity of $20 \mathrm{~s}$ sonicates from $A$. brasilense strain $\mathrm{Cd} \mathrm{H}$-cells, as determined by the percentage of aggregation of L-cells after $2 \mathrm{~h}$ incubation

Controls were L-cells incubated in phosphate buffer. Each value represents the mean of three replicates from one of three similar experiments. Different letters $(a-c)$ indicate significant differences at $P=0 \cdot 05$.

\begin{tabular}{|lccc|}
\hline Treatment & Aggregation $(\%)$ & $\begin{array}{c}\text { Protein content } \\
\left(\mathbf{m g ~ m}^{-1}\right)^{*}\end{array}$ & Flocculation \\
\hline Fresh sonicate & - & $0 \cdot 1$ & + \\
$37^{\circ} \mathrm{C}, 3 \mathrm{~h}$ & $8 \cdot 6^{\mathrm{a}}$ & $0 \cdot 09$ & + \\
Proteinase $\mathrm{K}, 3 \mathrm{~h}$ & $7 \cdot 6^{\mathrm{a}}$ & $0 \cdot 02$ & - \\
$100^{\circ} \mathrm{C}, 20 \mathrm{~min}$ & $3 \cdot 9^{\mathrm{b}}$ & $0 \cdot 03$ & - \\
Control & $2 \cdot 8^{\mathrm{be}}$ & - & - \\
\hline
\end{tabular}

*Values represent approximate protein concentration after subtracting the added proteinase $\mathrm{K}$.

t Sonicate kept at $4{ }^{\circ} \mathrm{C}$ prior to bioassay.

\section{Effects of sonication on the target cells used in the bioassay}

In the first experiments, cells used in bioassays were exposed to their own sonicate. The extent of aggregation between sonicated and non-sonicated L-cells to which sonicates were added was compared to estimate the role of sonication in aggregation. Sonicated cells showed a significantly higher extent of aggregation than the nonsonicated ones (Table 3) in all suspensions. Flocs of sonicated L-cells were again visible after $2-3 \mathrm{~h}$ incubation with sonicates. In sharp contrast, nonsonicated L-cells showed only weak flocculation after $20 \mathrm{~h}$ incubation (which may have resulted from stress induced by a long incubation period). Sonicated L-cells and sonicates from aggregating $\mathrm{H}$-cells were therefore used for further studies.

The fact that sonicated L-cells flocculated faster and more extensively than non-sonicated cells may be due to the removal of an extracellular cell-bound layer or component that impedes adhesion in non-sonicated Lcells. When centrifuged, the bacterial pellet obtained from H-cells is rough and cohesive, the cells clustering together with the pellet strongly attached to the bottom of the tube. Pellets obtained from L-cells are smooth, attach weakly to centrifuge tubes and are easily resuspended. Following sonication, the attachment of Lcells to the bottom of the centrifugation tubes is enhanced, resembling the behaviour of $\mathrm{H}$-cells.

\section{Influence of physiological status on aggregation}

The role of the metabolic status of the cells in the aggregation bioassay was investigated by adding $0 \cdot 1 \%$ $\mathrm{NaN}_{3}$ to the sonicated bacteria. Bacteria were immediately affected by this treatment as observed by microscope (loss of swimming behaviour and disruption of microaggregates) and plating (decrease in viability). $\mathrm{NaN}_{3}$-treated L-cells showed a significant decrease in the extent of aggregation in comparison to untreated Lcells. Flocculation did not occur in any $\mathrm{NaN}_{3}$ treatment even after $20 \mathrm{~h}$ incubation.

Addition of $\mathrm{NaN}_{3}$ to aggregating $\mathrm{Cd}$ cultures did not disrupt flocs but did disrupt microaggregates. Microaggregates were also disrupted by $\mathrm{NaN}_{3}$ using L-cells, explaining how the extent of aggregation in the $\mathrm{NaN}_{3}$ treated controls (resuspended in phosphate buffer with $\mathrm{NaN}_{3}$ ) could reach $0 \%$ (not shown). 
It is important to state that the effects of $\mathrm{NaN}_{3}$ are due to the azide and not the sodium ion, since resuspension of cells in saline solution (150 mM NaCl) does not cause a disruption of microaggregates and does not impede flocculation (Burdman et al., 1998).

\section{Effects of boiling and proteases on the aggregation- inducing activity of sonicates}

Both boiling and protease treatment using proteinase $\mathrm{K}$ significantly reduced the aggregation-inducing activity of the sonicate (Table 4). Moreover, L-cells did not flocculate in these treatments, in contrast to the flocculation observed with sonicates kept at 4 or $37^{\circ} \mathrm{C}$.

Treatment of the sonicate with boiled proteinase $\mathrm{K}$ (not shown) reduced aggregation in comparison to the untreated sonicate, but to a significantly lesser extent than unboiled proteinase $K$. Such a reduction in aggregation in comparison to the untreated sonicate could be due to residual enzymic activity, as proteinase $\mathrm{K}$ is known to be highly heat-stable. Treatment of the crude sonicate with trypsin did not affect its aggregationinducing capacity significantly. Protein content of sonicates was reduced by trypsin, but not as extensively as with proteinase $\mathrm{K}$ (not shown).

These results suggest that adhesive proteins present in the sonicate are at least partially responsible for the aggregation-inducing activity. Addition of bovine serum albumin to sonicated L-cells at a protein concentration similar to that of sonicates used in the bioassay did not increase aggregation above the control level (phosphate buffer) and flocculation was not observed (not shown). This indicates that increase in aggregation is not due to an increase in general protein content in the suspension.

\section{Involvement of OMPs in aggregation}

OMPs have been proposed to play a role as adhesins in invasion and adhesion processes in various Gramnegative bacteria. De Mot \& Vanderleyden (1991) purified the major OMP (MOMP) of Pseudomonas fluorescens and showed that it can strongly and selectively adsorb to plant roots. Similar results were obtained by Achouak et al. (1995) with a MOMP of Rahnella aquatilis. In both cases, these MOMPs were proposed to play a role in attachment and colonization of plant roots by the producing bacteria. Adhesive OMPs (generally porins) occur in Vibrio cholerae (Sasmal et al., 1992), Aeromonas bydrophila (Quinn \& Flower, 1995; Lee et al., 1997) and in an enteroaggregative strain of Escherichia coli (Debroy et al., 1995). Porins were shown to be involved in the invasion of epithelial cells by Salmonella typhimurium (Dorman et al., 1989) and Shigella flexneri (Bernardini et al., 1993).

To obtain a greater amount of the OMPs of Azospirillum, $\mathrm{H}$-cells were sonicated for 5 min while Lcells used in the bioassay were sonicated for $20 \mathrm{~s}$. Controls included a $20 \mathrm{~s}$ sonicate from $\mathrm{H}$-cells as in previous experiments. No qualitative differences be-

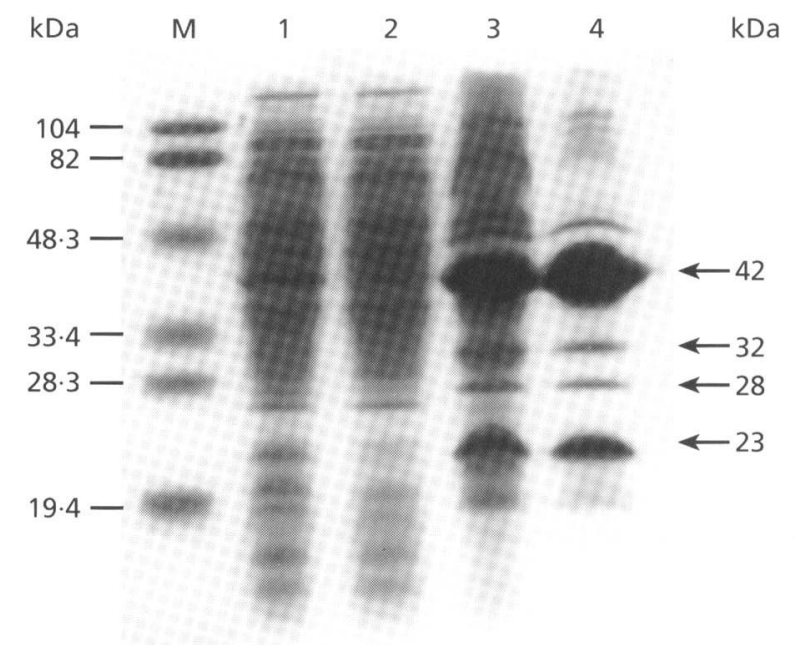

Fig. 1. SDS-PAGE of different fractions obtained from $\mathrm{H}$-cells of $A$. brasilense strain $\mathrm{Cd}$ tested for their aggregation-inducing capacity. Lanes: $M$, prestained markers; 1,5 min crude sonicate; 2 , free proteins; 3 , membrane proteins; 4 , OMPs. The arrows indicate the position of bands discussed in the text.

tween the protein profile of the $20 \mathrm{~s}$ and the $5 \mathrm{~min}$ sonicates were observed in SDS-PAGE (not shown), but twice as much protein was extracted with the $5 \mathrm{~min}$ sonicate (Table 2).

The total membrane protein fraction (Fig. 1, lane 3) was mostly composed of OMPs (approx. $82 \%$, based on image analysis). The aggregation-inducing capacity of the total membrane fraction was similar to that of the $20 \mathrm{~s}$ sonicate and was slightly higher than that of the free protein fraction. It should be pointed out that this result was obtained with a much lower protein concentration than with the crude extracts and with the free protein fraction. This is reflected in the high relative-enrichment value for the total membrane protein fraction (Table 5) in comparison to crude and free protein fractions.

Fractionation of the crude sonicates resulted in enrichment of OMPs as can be concluded by comparing the SDS-PAGE profile from this study (Fig. 1, lane 4) with the one obtained by Bachhawat \& Ghosh (1987), who previously isolated and characterized the OMPs from A. brasilense. The $23,28,32$ and $42 \mathrm{kDa}$ bands are shared by both profiles. Image analysis revealed the level of contamination of the OMP fraction by proteins other than OMPs to be approximately $5 \%$. The $42 \mathrm{kDa}$ major protein, found to be about $35 \%$ of total protein in the total membrane fraction (based on image analysis), constituted approximately $60 \%$ of the total protein in the OMP fraction.

The OMP fraction showed a significantly lower relative aggregation when compared to the $5 \mathrm{~min}$ sonicate fraction. However, the aggregation-inducing capacity of this fraction was significantly higher than that of the phosphate buffer control. Flocculation was also 
Table 5. Aggregation of L-cells of A. brasilense strain $\mathrm{Cd}$ after $2 \mathrm{~h}$ bioassay with different protein fractions from $\mathrm{H}$-cells

Each fraction was obtained from the same amount of bacteria sonicated for 5 min (except for the 'crude, $20 \mathrm{~s}$ sonication' treatment). Controls were L-cells incubated in phosphate buffer. Each value represents the mean of three replicates from one of three similar experiments. Different letters $(a-c)$ indicate significant differences at $P=0 \cdot 05$. 'Relative enrichment' values express the enrichment of the aggregation-inducing capacity of each fraction and are calculated as percentage aggregation/protein content.

\begin{tabular}{|lcccc|}
\hline Protein fraction & $\begin{array}{c}\text { Aggregation } \\
(\%)\end{array}$ & $\begin{array}{c}\text { Protein content } \\
\left(\mathbf{m g ~ m l}^{-1}\right)\end{array}$ & $\begin{array}{c}\text { Relative } \\
\text { enrichment }\end{array}$ & Flocculation \\
\hline Crude, 5 min sonication & $11 \cdot 6^{\mathrm{a}}$ & $0 \cdot 22$ & 53 & + \\
Crude, 20 s sonication & $9 \cdot 3^{\mathrm{ab}}$ & $0 \cdot 1$ & 93 & + \\
Free proteins & $6 \cdot 7^{\mathrm{b}}$ & $0 \cdot 2$ & 34 & + \\
Membrane proteins & $8 \cdot 6^{\mathrm{ab}}$ & $0 \cdot 03$ & 287 & + \\
OMPs & $6 \cdot 3^{\mathrm{b}}$ & $0 \cdot 01$ & 630 & + \\
Control & $1 \cdot 1^{\mathrm{b}}$ & - & - & - \\
\hline
\end{tabular}

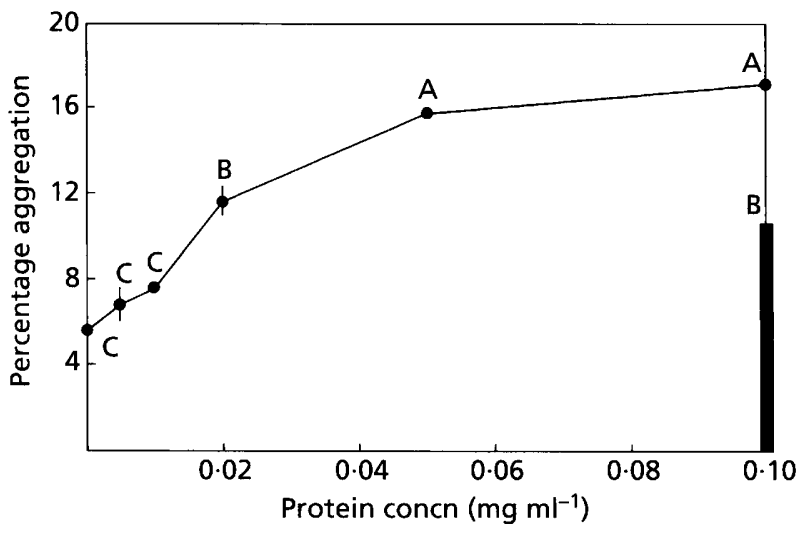

Fig. 2. Extent of aggregation of L-cells of $A$. brasilense strain Cd incubated at different concentrations of OMPs (O) or in the $20 \mathrm{~s}$ crude sonicate at $0.1 \mathrm{mg} \mathrm{ml}^{-1}$ (solid bar). Different letters $(A-C)$ indicate significant differences $(P=0.05)$ according to one-way analysis of variance.

observed in this treatment. Decrease in activity of the OMP fraction may be caused by loss or partial denaturation of proteins extracted from the membranes by use of a detergent. However, the relative-enrichment value of this fraction was the highest (Table 5).

As indicated before, the relatively highly active membrane protein fraction was mostly composed of OMPs. Furthermore, from the nature of the aggregation process itself, it can be inferred that if membrane-bound proteinaceous compounds that show adhesive properties are involved in the naturally occurring aggregation of $A$. brasilense, they should be OMPs, if not extracellular.

Concentration-dependent bioassays using the OMP fraction were carried out, showing that aggregation as well as flocculation increased with OMP concentration (Fig. 2). The extent of aggregation and flocculation reached using $0.02 \mathrm{mg}$ purified OMP fraction $\mathrm{ml}^{-1}$ necessitated $0 \cdot 1 \mathrm{mg}$ crude sonicate $\mathrm{ml}^{-1}$, therefore demonstrating an enrichment of aggregative capacity in the OMP fraction. Although $0.1 \mathrm{mg}$ purified OMP $\mathrm{ml}^{-1}$ caused an aggregation level significantly higher than that of the crude sonicate, the plateau reached indicates that a culture of cells has a limited potential for aggregation. This maximal aggregation could be determined by binding saturation of other compounds (such as EPS) involved in cell-to-cell adhesion. Treatment of the OMP fraction with proteinase $\mathrm{K}$ prevented aggregation and flocculation as observed with a $20 \mathrm{~s}$ crude sonicate (not shown).

To address the specificity of OMPs in the aggregation process of $A$. brasilense, OMPs from strain Cd were compared to OMPs from E. coli strain ML85 (obtained from H. Williams, University of Maryland, USA) and from P. fluorescens strain 417 (obtained from P. A. H. M. Bakker, Utrecht University, The Netherlands). Both the E. coli and P. fluorescens OMP fractions showed activities similar to that of $\mathrm{Cd}$ (not shown). Proteins with adhesive properties are thought to occur in the outer membrane of these genera (De Mot \& Vanderleyden, 1991; Debroy et al., 1995), not only in aggregative bacteria like Azospirillum. Although ruling out an exclusive role for OMPs in aggregation, it is possible that a more specific reaction of one or more of these proteins with other surface components forms the trigger for the aggregation reaction.

\section{Conclusions}

A bioassay that enables the study of biological factors involved in aggregation of Azospirillum brasilense was developed. The first results from this bioassay system suggest the involvement of protein(s) from the outer membrane in the aggregation phenomenon. Previous reports have suggested adhesive properties of OMPs (generally porins) of Gram-negative bacteria. The fact 
that the aggregation-inducing capacity of the crude sonicate was strongly affected by proteinase $\mathrm{K}$ but not by trypsin indicates that specific OMPs, such as the trypsin-insensitive $42 \mathrm{kDa}$ protein (Bachhawat \& Ghosh, 1987), may take part in that process. In addition, we have purified and are in the process of characterizing the $42 \mathrm{kDa}$ major protein from the OMP fraction (Fig. 1, lane 4). Partial amino acid sequencing of this protein showed a region with high similarity to other porins (unpublished results), thus strengthening the hypothesis that this protein is located in the outer membrane.

Protein profiles of different $A$. brasilense strains differing in their aggregation capacity were obtained using different extraction methods (Burdman et al., 1998). No differences in protein profiles that explain the differential aggregation behaviour between strains grown under the same conditions were found. The polar flagellum previously proposed to be involved in the first step of bacterial attachment to roots (Croes et al., 1993) has been shown not to be involved in aggregation (Burdman et al., 1998).

Previously published data support the hypothesis that EPS is involved in aggregation of Azospirillum (Sadasivan \& Neyra, 1985; Del Gallo et al., 1989; Michiels et al., 1990; Arunakumari et al., 1992; Katupitiya et al., 1995; Pereg-Gerk et al., 1998; Burdman et al., 1998). We propose that under certain growth conditions, protein(s) from the outer membrane could interact with EPS, leading to aggregation and flocculation. Recently, Castellanos et al. (1998) suggested that several cell-wall proteins extracted from various $A$. brasilense strains exhibit lectin-like activities. The strains differing in aggregation capacity had the same OMPs profile and no strain showed differences caused by growth under a high or low $\mathrm{C}: \mathrm{N}$ ratio (unpublished data). However, the strains did differ in EPS content with correlation to aggregation extent (Burdman et al., 1998). Therefore, we suggest that the $\mathrm{OMP}(\mathrm{s})$ involved in aggregation is (are) constitutively present in A. brasilense. Differences in the extent of aggregation between the various strains might be related to the amount, composition and structure of EPS present. The interaction between the molecular factors leading to aggregation does not seem to be specific, since OMPs from E. coli and P. fluorescens induced aggregation as effectively as OMPs of Azospirillum.

We are currently investigating the differences in EPS composition and structure between different strains and under different growth conditions. An in-depth study on the OMPs of A. brasilense (especially the $42 \mathrm{kDa}$ MOMP) is also being undertaken to elucidate the 'participants' involved in cell-to-cell adhesion of $A$. brasilense during aggregation.

\section{ACKNOWLEDGEMENTS}

We thank J. Vanderleyden and S. Moens from the F. A. Janssens Laboratorium voor Genetica of the Katholieke Universiteit Leuven (Belgium) for the Tn5 mutant FAJ0204. We also thank C. Elmerich from the Unité de Physiologie
Cellulaire, Département des Biotechnologies, Institut Pasteur (France) for the $\operatorname{Tn} 5$ mutant Sp72002. This research was supported by the Israel Science Foundation, founded by the Academy of Sciences and Humanities, and by the Hebrew University Intramural Fund Basic Research Awards.

\section{REFERENCES}

Achouak, W., De Mot, R. \& Heulin, T. (1995). Purification and partial characterization of an outer membrane protein involved in the adhesion of Rhanella aquatilis to wheat roots. FEMS Microbiol Ecol 16, 19-24.

Arunakumari, A., Lamm, R. B. \& Neyra-Estens, C. A. (1992). Changes in cell surface properties of azospirilla in relation to cell pleomorphism and aggregation. Symbiosis 13, 291-305.

Bachhawat, A. K. \& Ghosh, S. (1987). Isolation and characterization of the outer membrane proteins of Azospirillum brasilense. J Gen Microbiol 133, 1751-1758.

Bernardini, M. L., Sanna, M. G., Fontaine, A. \& Sansonetti, P. (1993). OmpC is involved in invasion of epithelial cells by Shigella flexneri. Infect Immun 61, 3625-3635.

Bradford, M. M. (1976). A rapid and sensitive method for the quantitation of microgram quantities of protein utilizing the principle of protein-dye binding. Anal Biochem 72, 248-254.

Burdman, S., Jurkevitch, E., Schwartsburd, B., Hampel, M. \& Okon, Y. (1998). Aggregation in Azospirillum brasilense: effects of chemical and physical factors and involvement of extracellular components. Microbiology 144, 1989-1999.

Calleja, J. B. (1984). Microbial Aggregation. Boca Raton, FL: CRC Press.

Castellanos, T., Ascencio, F. \& Bashan, Y. (1998). Cell-surface lectins of Azospirillum spp. Curr Microbiol 36, 241-244.

Croes, C. L., Moens, S., Van Bastelaere, E., Vanderleyden, J. \& Michiels, K. W. (1993). The polar flagellum mediates Azospirillum brasilense adsorption to wheat roots. J Gen Microbiol 139, 2261-2269.

Debroy, C., Yealy, J., Wilson, R. A., Bhan, M. K. \& Kumar, R. (1995). Antibodies raised against the outer membrane protein interrupt adherence of enteroaggregative Escherichia coli. Infect Immun 63, 2873-2879.

Del Gallo, M., Negi, M. \& Neyra, C. A. (1989). Calcofluor and lectin-binding exocellular polysaccharides of Azospirillum brasilense and Azospirillum lipoferum. J Bacteriol 171, 3504-3510.

De Mot, R. \& Vanderleyden, J. (1991). Purification of a rootadhesive outer membrane protein of root-colonizing Pseudomonas fluorescens. FEMS Microbiol Lett 81, 323-328.

De Troch, P. \& Vanderleyden, J. (1996). Surface properties and motility of Rhizobium and Azospirillum in relation to plant root attachment. Microb Ecol 32, 149-169.

Dorman, C. J., Chatfield, S., Higgins, C. F., Hayward, C. \& Dougan, G. (1989). Characterization of porin and $\operatorname{ompR}$ mutants of a virulent strain of Salmonella typhimurium: ompR mutants are attenuated in vivo. Infect Immun 57, 2136-2140.

Dufrêne, Y. F. \& Rouxhet, P. C. (1996). Surface composition, surface properties, and adhesiveness of Azospirillum brasilensevariation during growth. Can J Microbiol 42, 548-556.

Dufrêne, Y. F., Boonaert, C. J. P. \& Rouxhet, P. C. (1996a). Adhesion of Azospirillum brasilense: role of proteins at the cellsupport interface. Colloids Surf 7, 113-128.

Dufrêne, Y. F., Vermeiren, H., Vanderleyden, J. \& Rouxhet, P. C. (1996b). Direct evidence for the involvement of extracellular 
proteins in the adhesion of Azospirillum brasilense. Microbiology 142, 855-865.

Eggset, G., Stenberg, E. \& Kjosbakken, J. (1983). Flocculation of a Methylomonas sp.: possible involvement of a surface protein. $J$ Gen Microbiol 129, 3611-3617.

Eskew, D. L., Focht, D. D. \& Ting, I. P. (1977). Nitrogen fixation, denitrification and pleomorphic growth in highly pigmented Spirillum lipoferum. Can J Microbiol 34, 582-585.

Katupitiya, S., Millet, J., Vesk, M., Viccars, L., Zeman, A., Lidong, Z., Elmerich, C. \& Kennedy, I. R. (1995). A mutant of Azospirillum brasilense $\mathrm{Sp} 7$ impaired in flocculation with a modified colonization pattern and superior nitrogen fixation in association with wheat. Appl Environ Microbiol 61, 1987-1995.

Laemmli, U. K. (1970). Cleavage of structural proteins during the assembly of the head of bacteriophage T4. Nature 227, 680-685.

Lee, S. Y., Yin, Z., Ge, R. \& Sin, M. (1997). Isolation and characterization of fish Aeromonas bydrophila adhesins important for in vitro epithelial cell invasion. J Fish Dis 20, 169-175.

Madi, L. \& Henis, Y. (1989). Aggregation in Azospirillum brasilense $\mathrm{Cd}$ : conditions and factors involved in cell-to-cell adhesion. Plant Soil 115, 89-98.

Madi, L., Kessel, M., Sadovnik, E. \& Henis, Y. (1988). Electron microscopic studies of aggregation and pellicle formation in Azospirillum spp. Plant Soil 109, 115-121.

Marsh, P. D. \& Bradshaw, D. J. (1995). Dental plaque as a biofilm. J Ind Microbiol 15, 169-175.

Michiels, K., Verreth, C. \& Vanderleyden, J. (1990). Azospirillum lipoferum and Azospirillum brasilense surface polysaccharide mutants that are affected in flocculation. J Appl Bacteriol 69, $705-711$

Michiels, K. W., Croes, C. L. \& Vanderleyden, J. (1991). Two different modes of attachment of Azospirillum brasilense Sp7 to wheat roots. J Gen Microbiol 137, 2241-2246.

Nikitina, V. E., Alenkina, S. A., Ponomareva, E. G. \& Savenkova, N. N. (1996). Role of lectins of the cell surface of azospirilla in association with wheat roots. Mikrobiologiya 65, 165-170 (in Russian).
Nur, I., Steinitz, Y. L., Okon, Y. \& Henis, Y. (1981). Carotenoid composition and function in nitrogen-fixing bacteria of the genus Azospirillum. J Gen Microbiol 123, 27-32.

Okon, Y. \& Labandera-Gonzalez, C. A. (1994). Agronomic applications of Azospirillum. An evaluation of 20 years worldwide field inoculation. Soil Biol Biochem 26, 1591-1601.

Okon, Y., Albrecht, S. L. \& Burris, R. H. (1977). Methods for growing Spirillum lipoferum and for counting it in pure culture and in association with plants. Appl Environ Microbiol 33, 85-88.

Pereg-Gerk, L., Paquelin, A., Gounon, P., Kennedy, I. R. \& Elmerich, C. (1998). A transcriptional regulator of the LuxRUhpA family, FlcA, controls flocculation and wheat root surface colonization by Azospirillum brasilense Sp7. Mol Plant-Microbe Interact 11, 177-187.

Quinn, D. M. \& Flower, R. L. P. (1995). 'Porin-adhesins' of Aeromonas hydrophila? Med Microbiol Lett 4, 426-436.

Sadasivan, L. \& Neyra, C. A. (1985). Flocculation in Azospirillum brasilense and Azospirillum lipoferum: exopolysaccharides and cyst formation. J Bacteriol 163, 716-723.

Sasmal, D., Guhathakurta, B., Ghosh, A. N., Pal, C. R. \& Datta, A. (1992). $N$-acetyl-D-glucosamine-specific lectin purified from Vibrio cholerae 01. FEMS Microbiol Lett 98, 217-224.

Schloter, M., Moens, S., Croes, C., Reidel, G., Esquenet, M., De Mot, R., Hartmann, A. \& Michiels, K. (1994). Characterization of cell surface components of Azospirillum brasilense $\mathrm{Sp} 7$ as antigenic determinants for strain-specific monoclonal antibodies. Microbiology 140, 823-828.

Tarrand, J. J., Krieg, N. R. \& Dobereiner, J. (1978). A taxonomic study of the Spirillum lipoferum group with the description of a new genus, Azospirillum gen. nov. and two species, Azospirillum lipoferum (Beijerinck) comb. nov. and Azospirillum brasilense sp. nov. Can J Microbiol 24, 967-980.

Wai, S. N., Takade, A. \& Amako, K. (1996). The hydrophobic surface protein layer of enteroaggregative Escherichia coli strains. FEMS Microbiol Lett 135, 17-22.

Received 11 November 1998; revised 3 February 1999; accepted 16 February 1999. 